INTERNATIONAL JOURNAL OF SCIENTIFIC RESEARCH

\title{
ATTITUDE AND PRACTICING BEHAVIOUR AMONG HEALTHCARE PROFESSIONALS REGARDING HANDWASHING:A TOOL TO PREVENT EMERGING AND RE-EMERGING INFECTIONS.
}

\section{Community Medicine}

Dr. Syed Waseem Postgraduate Student, Department of Dermatology, Venereology and Leprosy Tahir

Dr. Sahila Nabi $\quad$ Postgraduate Student, Department of Community Medicine GMC Srinagar.

Dr. Shazia Javaid** $\begin{aligned} & \text { Postgraduate Student, Department of Cor } \\ & \text { College Srinagar. *Corresponding Author }\end{aligned}$

\section{ABSTRACT}

Background: Hand hygiene is one of the most effective ways to control health care related infection. Every year millions of patients around the world are affected by infections that are transmitted by the health-care professionals(HCPs).

Rationale: Nurses and physicians are the main health care workers contacting with patients, representing the vector in the chain of infection. Thus, assessing their knowledge, attitude and practice regarding hand hygiene is very important to decrease the incidence of health care related infection and to improve quality of care.

Objective: The objective of our study was to assess the knowledge, attitude and practices of handwashing among healthcare professionals of Kashmir Division.

Methods: This study was an institutional based cross sectional study, conducted in various healthcare institutions of Kashmir Division which were selected randomly. A predesigned questionnaire was used to collect the data from the participants. The questionnaires contained questions about four different parts which included sociodemographic characteristics, knowledge of hand washing, attitude and practice of hand washing among healthcare professionals. The questionnaires were distributed to various healthcare professionals working in wards, emergency department, laboratories, outpatient departments, injection and dressing rooms, EPI unit and others. The distributed questionnaires were then collected back.

Results: A total of 110 participants were included. Out of total 110 participants, $53 \%$ were male ,36\% were nurses $36 \%$ of health professionals were working in IPD (In Patient Department).

$89 \%$ of the participants agreed that, direct or indirect contacts are the most important routes for transmission of hospital-acquired infections, $97 \%$ agreed that proper and consistent hand washing prevents infections in health facilities, $100 \%$ agreed that health professionals should always wash their hands immediately when they arrive at health institutions, $98 \%$ said that they knew steps of handwashing(WHO)/rules of hand hygiene, $91 \%$ agreed that hand washing is the single most effective mechanism to prevent spread of infection and $95 \%$ agreed that wearing jewellery, artificial fingernails, damaged skin and regular use of hand cream are associated with increased likelihood of colonisation of hands with harmful germs.

$83 \%$ of the participants said that they are committed to the proper rules of hand hygiene all the time, $78 \%$ said they comply with rules of hand hygiene even in emergencies, $80 \%$ said that they think when they are wearing gloves it is not necessary to wash hands, $92 \%$ feel irritated when others don't follow hand hygiene rules, $95 \%$ advice others to follow the rules of hand hygiene and $97 \%$ said it is easy for you to follow rules of hand hygiene.

$40 \%$ (each) of the participants said that they always and usually wash hands before touching a patient, $100 \%$ of the participants said that they always wash hands before performing aseptic and clean procedures, $100 \%$ of the participants said that they always wash hands after being at risk of exposure to body fluids and $95 \%$ of patients said that they wash hands after coming to and before leaving the hospital.

DISCUSSION

In this study we had a total of 110 participants. Health professionals had a satisfactory knowledge of hand hygiene but some lacunae are still there as is evident in the result part. Thus from this study we conclude adherence to handwashing is lacking among health professionals, so we need to have regular handwashing sessions for health professionals which will regularly sensitize them, also we need to address the reasons of this poor adherence both at the administrative and personal level. We also recommend to conduct more studies in this field so as to highlight the shortcomings in hand hygiene and then to improve upon them.

\section{KEYWORDS}

\section{INTRODUCTION}

Hand hygiene is one of the most effective ways to control health care related infection. World Health Organization (WHO) introduced "My five moments for hand washing" to minimize problems related to hand washing. These five moments that call for the use of hand washing include the moment before touching a patient, before performing aseptic and clean procedures, after being at risk of exposure to body fluids, after touching a patient, and after touching patient surroundings (1). Every year millions of patients around the world are affected by infections that are transmitted by the health-care professionals(HCPs). (2)(3). Most of these infections can be prevented through a simple precautionary measure of proper hand wash.

Unfortunately, compliance with the hand hygiene guidelines provided by the WHO is usually poor among the health-care professionals( $\mathrm{HCPs}$ ), and the hand hygiene equipment is not up to standards. Nurses and physicians are the main health care workers contacting with patients, representing the vector in the chain of infection. Thus, assessing their knowledge, attitude and practice regarding hand hygiene is very important to decrease the incidence of health care related infection and to improve quality of care.

\section{OB.JECTIVE}

The objective of our study was to assess the knowledge, attitude and practices of handwashing among healthcare professionals of
Kashmir Division

\section{METHODOLOGY}

STUDY AREA: The study was conducted in various healthcare institutions viz Sub Centres, Primary Health Centres, Sub District Hospitals and Tertiary Care Hospitals of Kashmir Division.

STUDY DESIGN: It was an institution based cross sectional study.

STUDY POPULATION: The study included healthcare professionals working in various healthcare institutions viz Sub Centres, Primary Health Centres, Sub District Hospitals and Tertiary Care Hospitals of Kashmir Division.

\section{ELIGIBILITY CRITERIA:}

Inclusion Criteria Healthcare professionals of various healthcare institutions (Sub Centres, Primary Health Centres and Sub District Hospitals of Kashmir Division) who were available during data collection and interested in participating in the study were included.

Exclusion Criteria Health professionals who were not interested in participating in the study were excluded.

Sample Size It was an open sample.

Sampling Technique Simple random sampling technique was used to International Journal of Scientific Research 
select the study participants.

\section{PROCEDURE}

This study was an institutional based cross sectional study, conducted in various healthcare institutions of Kashmir Division which were selected randomly. A predesigned questionnaire was used to collect the data from the participants. The questionnaires contained questions about four different parts which included sociodemographic characteristics, knowledge of hand washing, attitude and practice of hand washing among healthcare professionals. The questionnaires were distributed to various healthcare professionals working in wards, emergency department, laboratories, outpatient departments, injection and dressing rooms, EPI unit and others. The distributed questionnaires were then collected back.

Data Analysis: Data analysis was done using SPSS version 23 .

\section{RESULTS}

Table 1: Socio Demographic Characteristics

\begin{tabular}{|l|l|l|l|}
\hline FACTOR & FREQUENCY & PERCENTAGE \\
\hline SEX & Male & 58 & 52.7 \\
\cline { 2 - 4 } & Female & 52 & 47.3 \\
\hline \multirow{5}{*}{ JOB TITLE } & Doctors & 22 & 20.0 \\
\cline { 2 - 4 } & Pharmacists & 10 & 9.0 \\
\cline { 2 - 4 } & FMPHW & 18 & 16.4 \\
\cline { 2 - 4 } & Nurses & 40 & 36.4 \\
\cline { 2 - 4 } & Technicians & 20 & 18.2 \\
\hline DEPARTMENT & Outpatient & 38 & 34.5 \\
\cline { 2 - 4 } & Inpatient & 40 & 36.4 \\
\cline { 2 - 4 } & Emergency & 12 & 10.9 \\
\cline { 2 - 4 } & $\begin{array}{l}\text { Operation } \\
\text { theatre }\end{array}$ & 20 & 18.2 \\
\hline
\end{tabular}

Table 1 shows the socio demographic characteristics of the study participants. Out of total 110 participants, $53 \%$ were male ,36\% were nurses $36 \%$ of health professionals were working in IPD (In Patient Department)

Table 2: Knowledge Of Handwashing Among The Participants

\begin{tabular}{|l|l|l|l|}
\hline VARIABLE & Yes & No & $\begin{array}{l}\text { I Don't } \\
\text { Know }\end{array}$ \\
\hline $\begin{array}{l}\text { 1.Direct or indirect contacts are the } \\
\text { most important routes for } \\
\text { transmission of hospital-acquired } \\
\text { infections }\end{array}$ & $98(89.0)$ & $6(5.5)$ & $6(5.5)$ \\
\hline $\begin{array}{l}\text { 2. Proper and consistent hand washing } \\
\text { prevents infections in health facilities }\end{array}$ & $107(97.3)$ & $1(0.9)$ & $2(1.8)$ \\
\hline $\begin{array}{l}\text { 3.There is no need for hand washing } \\
\text { for those who perform their activity } \\
\text { with caution }\end{array}$ & $42(38.2)$ & $67(60.9)$ & $1(0.9)$ \\
\hline $\begin{array}{l}\text { 4.There is no need of hand washing } \\
\text { if gloves are properly worn }\end{array}$ & $51(46.4)$ & $57(51.8)$ & $2(1.8)$ \\
\hline $\begin{array}{l}\text { 5.Health professionals should always } \\
\text { wash their hands immediately when } \\
\text { they arrive at health institutions }\end{array}$ & $110(100)$ & $0(0)$ & $0(0)$ \\
\hline $\begin{array}{l}\text { 6.Do you know steps of } \\
\text { handwashing(WHO)/rules of hand } \\
\text { hygiene }\end{array}$ & $108(98.2)$ & $2(1.8)$ & $0(0)$ \\
\hline $\begin{array}{l}\text { 7.Hands should be washed at least } \\
\text { for 10-15 seconds }\end{array}$ & $39(35.5)$ & $59(53.6)$ & $12(10.9)$ \\
\hline $\begin{array}{l}\text { 8.Using disinfectants during hand } \\
\text { washing decreases bacterial load on } \\
\text { hands }\end{array}$ & $62(56.4)$ & $47(42.7)$ & $1(0.9)$ \\
\hline $\begin{array}{l}\text { 9.Alcohol has the ability to eradicate } \\
\text { micro-organisms compared to water }\end{array}$ & $68(61.8)$ & $39(35.5)$ & $3(2.7)$ \\
\hline $\begin{array}{l}\text { 10.Hand washing is the single most } \\
\text { effective mechanism to prevent } \\
\text { spread of infection }\end{array}$ & $100(90.9)$ & $7(6.4)$ & $3(2.7)$ \\
\hline $\begin{array}{l}\text { 11.Wearing jewellery, artificial } \\
\text { fingernails, damaged skin and } \\
\text { regular use of hand cream are } \\
\text { associated with increased likelihood } \\
\text { of colonisation of hands with } \\
\text { harmful germs }\end{array}$ & $104(94.6)$ & $4(3.6)$ & $2(1.8)$ \\
\hline
\end{tabular}

Table 2 Shows knowledge of handwashing among the participants. $89 \%$ of the participants agreed that, direct or indirect contacts are the most important routes for transmission of hospital-acquired infections, 97\% agreed that proper and consistent hand washing prevents infections in health facilities, $100 \%$ agreed that health professionals should always wash their hands immediately when they arrive at health institutions, $98 \%$ said that they knew steps of handwashing(WHO)/rules of hand hygiene, $91 \%$ agreed that hand washing is the single most effective mechanism to prevent spread of infection and $95 \%$ agreed that wearing jewellery, artificial fingernails, damaged skin and regular use of hand cream are associated with increased likelihood of colonisation of hands with harmful germs

Table 3: Attitude Regarding Handwashing Among The Participants

\begin{tabular}{|l|l|l|l|}
\hline Variable & Yes & No & Sometimes \\
\hline $\begin{array}{l}\text { 1.Are you committed to the proper } \\
\text { rules of hand hygiene all the time ? }\end{array}$ & $91(82.7)$ & $0(0)$ & $19(17.3)$ \\
\hline $\begin{array}{l}\text { 2.Do you comply with rules of } \\
\text { hand hygiene even in } \\
\text { emergencies? }\end{array}$ & $86(78.2)$ & $0(0)$ & $24(21.8)$ \\
\hline $\begin{array}{l}\text { 3.Do you think when you are } \\
\text { wearing gloves it is not necessary } \\
\text { to wash your hands? }\end{array}$ & $22(20)$ & $88(80)$ & $(0)$ \\
\hline $\begin{array}{l}\text { 4.Do you feel irritated when others } \\
\text { don't follow hand hygiene rules? }\end{array}$ & $101(91.9)$ & $0(0)$ & $9(8.1)$ \\
\hline $\begin{array}{l}\text { 5.Do you advice others to follow } \\
\text { the rules of hand hygiene? }\end{array}$ & $104(94.5)$ & $0(0)$ & $6(5.5)$ \\
\hline $\begin{array}{l}\text { 6.Is it easy for you to follow rules } \\
\text { of hand hygiene? }\end{array}$ & $107(97.3)$ & $1(0.9)$ & $2(1.8)$ \\
\hline
\end{tabular}

TABLE 3 shows attitude regarding handwashing among the participants. $83 \%$ of the participants said that they are committed to the proper rules of hand hygiene all the time, $78 \%$ said they comply with rules of hand hygiene even in emergencies, $80 \%$ said that they think when they are wearing gloves it is not necessary to wash hands, $92 \%$ feel irritated when others don't follow hand hygiene rules, $95 \%$ advice others to follow the rules of hand hygiene and $97 \%$ said it is easy for you to follow rules of hand hygiene.

Table 4: Practice Of Handwashing Among The Participants

\begin{tabular}{|c|c|c|}
\hline Variable & Response & Frequency \\
\hline \multirow{5}{*}{ 1.Wash hands before touching a patient } & Always & $44(40)$ \\
\hline & Usually & $44(40)$ \\
\hline & Often & $0(0)$ \\
\hline & Sometimes & $22(20)$ \\
\hline & Never & $0(0)$ \\
\hline \multirow{5}{*}{$\begin{array}{l}\text { 2. Wash hands before performing aseptic } \\
\text { and clean procedures }\end{array}$} & Always & $110(100)$ \\
\hline & Usually & $0(0)$ \\
\hline & \begin{tabular}{|l|l} 
Often \\
\end{tabular} & $0(0)$ \\
\hline & Sometimes & $(0)$ \\
\hline & Never & $(0)$ \\
\hline \multirow{5}{*}{$\begin{array}{l}\text { 3. Wash hands after being at risk of } \\
\text { exposure to body fluids }\end{array}$} & Always & $110(100)$ \\
\hline & Usually & $(0)$ \\
\hline & Often & $(0)$ \\
\hline & Sometimes & $(0)$ \\
\hline & Never & $(0)$ \\
\hline \multirow[t]{5}{*}{ 4. Wash hands after touching a patient } & Always & $46(41.8)$ \\
\hline & Usually & $62(56.4)$ \\
\hline & Often & $0(0)$ \\
\hline & Sometimes & $2(1.8)$ \\
\hline & Never & $0(0)$ \\
\hline \multirow{5}{*}{$\begin{array}{l}\text { 5.Wash hands after touching patients } \\
\text { surroundings }\end{array}$} & Always & $62(56.4)$ \\
\hline & Usually & $42(38.2)$ \\
\hline & Often & $2(1.8)$ \\
\hline & Sometimes & $4(3.6)$ \\
\hline & Never & $(0)$ \\
\hline \multirow{5}{*}{$\begin{array}{l}\text { 6.Use alcohol based hand rub for hand } \\
\text { hygiene }\end{array}$} & Always & $24(21.8)$ \\
\hline & Usually & $46(41.8)$ \\
\hline & Often & $40(36.4)$ \\
\hline & \begin{tabular}{|l} 
Sometimes \\
\end{tabular} & $0(0)$ \\
\hline & Never & $0(0)$ \\
\hline \multirow{5}{*}{$\begin{array}{l}\text { 7. Wash hands after coming to and before } \\
\text { leaving the hospital }\end{array}$} & Always & $104(94.5)$ \\
\hline & Usually & $0(0)$ \\
\hline & Often & $0(0)$ \\
\hline & \begin{tabular}{|l|} 
Sometimes \\
\end{tabular} & $6(5.5)$ \\
\hline & Never & $0(0)$ \\
\hline
\end{tabular}


TABLE 4 shows practice of handwashing among the participants. $40 \%$ (each) of the participants said that they always and usually wash hands before touching a patient, $100 \%$ of the participants said that they always wash hands before performing aseptic and clean procedures, $100 \%$ of the participants said that they always wash hands after being at risk of exposure to body fluids and $95 \%$ of patients said that they wash hands after coming to and before leaving the hospital.

\section{DISCUSSION}

In this study we had 110 participants. In the knowledge part, $61 \%$ of the participants said there is no need for hand washing for those who perform their activity with caution and $52 \%$ of the participants said that there is no need of hand washing if gloves are properly worn. In other domains of knowledge part the answers were quite satisfactory as is already shown in results, but from these responses we see that there is a need to impart more knowledge to health professionals about handwashing. In attitude part the responses were quite satisfactory except for that $80 \%$ of participants said that it is not necessary to wash hands when we are wearing gloves, so there is a need to increase their knowledge regarding handwashing which will bring a change in their attitudes towards handwashing. In the practise part again the responses are quite satisfactory but some lacunae are still there as is evident in the result part. Thus from this study we conclude adherence to handwashing is lacking among health professionals, so we need to have regular handwashing sessions for health professionals which will regularly sensitize them, also we need to address the reasons of this poor adherence both at the administrative and personal level. We also recommend to conduct more studies in this field so as to highlight the shortcomings in hand hygiene and then to improve upon them.

\section{REFERENCES}

1. Sax H, Allegranzi B, Uc I, Pittet D. ' My five moments for hand hygiene ': a user-centred design approach to understand, train, monitor and report hand hygiene. 2007;

2. Pourakbari B, Rezaizadeh G, Mahmoudi S, Mamishi S, Infectious P. Epidemiology of nosocomial infections in pediatric patients in an Iranian referral hospital. 2012;204-6.

3. Mulu W, Kibru G, Beyene G, Damtie M. Associated Risk factors for Postoperative Nosocomial infections among Patients admitted at Felege Hiwot Referral Hospital, Bahir Dar, Northwest Ethiopia. 2013;2(6):140-7. 